\title{
How online reviews \& ratings websites sites are changing the tourism \& hospitality sector
}

\author{
Dr. Kanchan Agarwal \\ Victoria University, Melbourne, Australia.
}

OScholedge International Journal of Business Policy \& Governance (ISSN 2394-3351), Vol.02, Issue 12 (2015) pp1-3. Published by: Scholedge R\&D Center [www.theSCHOLEDGE.org] [Email: sijbpg@scholedge.org]

\begin{abstract}
Travel sites have been around since the 1990s, when Expedia, Travelocity and other occasion booking locales were dispatched, permitting explorers to contrast flight and lodging costs and the snap of a mouse. With data no more controlled by travel operators or covered up in business organizes, the travel business was reformed, as more noteworthy straightforwardness cut costs.
\end{abstract}

Keywords: Tourism, Hospitality, Online reviews, rating websites

\section{Introduction}

Today, the industry is in the throes of another upset - this time changing administration quality. Internet rating stages - spend significant time in inns (TripAdvisor), eateries (Zagat), flats (Airbnb) and taxis (Uber) - permit explorers to trade audits and encounters for all to see.

Cordiality organizations are presently positioned, broke down and analyzed not by industry experts, but rather by the very individuals for whom the administration is planned - the client. This has fashioned another relationship in the middle of purchaser and vender. Clients have dependably voted with their feet; they can now disclose their choice to any individual who is intrigued. Accordingly, organizations are substantially more responsible, frequently in particular ways, which makes capable motivations to enhance administration.

Albeit a few perusers won't not enjoy gossipy reports of curt bellboys in Berlin or failing lodging hairdryers in Houston, the genuine force of online audits lies in the individual stories, as well as in the sites' ability to total an extensive volume of appraisals.

The effect can't be exaggerated. Organizations that pull in top evaluations can appreciate exponential development, as new clients are pulled in by great general surveys and in this way give yet more (positive) input. So incredible is the impact of online evaluations that numerous organizations now enlist advanced notoriety directors to guarantee a positive online character.

The framework is not generally righteous. Loathsome administrators are known not fake audit administrations to support evaluations. Clients, as well, can be insincere or more 
terrible, participate in extortion, which happens, as TripAdvisor clarifies, "when a visitor undermines to compose a negative audit unless an interest for a discount, overhaul, or other solicitation is met."

Luckily, innovation is countering this abuse of appraisals. Calculations can as of now distinguish fake audits by recognizing reliably positive (or negative) conclusions from the same commentator. Geolocation following can guarantee that just clients who have really utilized an administration can express a feeling (similar to the case with Airbnb).

To be sure, obstreperous commentators are being tested as a consequence of another, rather astonishing advancement: while clients might express a conclusion around an administration, the administration supplier can likewise rate its clients, as Uber has illustrated. To be sure, it is not incomprehensible that well known lodgings may one day pick their visitors.

Customary connections in the middle of shoppers and makers are separating in different ways, as well. The ascent of the "sharing economy," in which resources -, for example, an auto, a parking spot or an extra room - are shared inside of groups creates equal goodwill, as well as foggy spots the refinement in the middle of purchaser and vender.

Not each administration, nonetheless, has been touched by online appraisals. The effect of evaluations relies on upon whether the regular purchaser really peruses online surveys before settling on a choice. While it is progressively regular to do as such when, say, booking an inn room, it is a great deal less so when settling on, say, bars on a bustling road (the persisting impoliteness of Parisian servers bears witness to that).

Yet even administration foundations that depend on "control bid" to pull in clients might soon discover their days numbered. The expansion of "expanded reality" - an overlay of advanced data (as created by Google Glass, among others) - guarantees to change ordinary exercises into a computerized/physical cross breed involvement in which client criticism is in a split second and consistently accessible to customers.

\section{Conclusion}

The last holdout against the raters will be administrations for which clients must choose between limited options, normally imposing business models or government offices, for example, air terminals. Singapore's Changi Airport is an uncommon special case: it requests client appraisals every step of the way, by means of input screens with lively, touchempowered smiley-face emoticons that demand voyagers' sentiments on everything from the proficiency of migration administration to the cleanliness of toilets.

Obviously, numerous created economies fall behind, in any event for the present. Be that as it may, the written work is, actually, on the divider - or possibly on the screen. In reality, on the off chance that you are perusing this online and can't help contradicting me, you can clarify why in the remarks area going.

\section{References}


Bernoff, J., \& Li, C. (2008). Groundswell: Winning in a world transformed by social technologies. Boston: Harvard Business School Publishing.

Bloomberg, J., \& Schmelzer, R. (2006). Service orient or be doomed!: how service orientation will change your business. John Wiley \& Sons.

Christensen, C. M. (1997). The Innovator|'s Dilemma: The Revolutionary Book that Will Change the Way You Do Business (Collins Business Essentials).

Hewitt, H. (2005). Blog: Understanding the information reformation that's changing your world. Thomas Nelson Inc.

Kahaner, L. (1997). Competitive intelligence: how to gather analyze and use information to move your business to the top. Simon and Schuster.

Slywotzky, A. J., Morrison, D., \& Weber, K. (2001). How digital is your business?. Crown Business.

Steffes, E. M., \& Burgee, L. E. (2009). Social ties and online word of mouth.Internet Research, 19(1), 42-59.

Tapscott, D. (2009). Grown up digital (Vol. 361). New York: McGraw-Hill.

Thompson, A. A., Strickland, A. J., Gamble, J. E., \& Zeng'an Gao. (2008).Crafting and executing strategy: The quest for competitive advantage: Concepts and cases (Vol. 19). McGraw-Hill/Irwin.

Weber, L. (2009). Marketing to the social web: How digital customer communities build your business. John Wiley \& Sons.

Weinstein, M. I. (1977). The effect of a rating change announcement on bond price. Journal of Financial Economics, 5(3), 329-350. 